\title{
Online dissolved gas analysis used for transformers - possibilities, experiences, and limitations
}

\author{
Christof Riedmann (D) - Uwe Schichler · Wolfgang Häusler · Wolfgang Neuhold
}

Received: 5 October 2021 / Accepted: 3 November 2021 / Published online: 16 February 2022

(C) The Author(s) 2022

\begin{abstract}
At a time when the optimal utilization of resources is becoming ever more important, the condition monitoring of electrical equipment is also becoming increasingly essential. The dissolved gas analysis (DGA), an internationally accepted method for the condition assessment of transformers, plays a key role in this respect. By continuously monitoring the key gases in a transformer, incipient faults can be detected at an early stage and suitable maintenance measures can be initiated. This ability to plan maintenance measures may provide the key to cutting costs and increasing the overall system reliability. In free-breathing transformers, degassing or gas dissolving can occur over time, which may influence the interpretation basis of the DGA. The reason for this is that molecules always strive for equal distribution in a chemical-physical system. Various theories, which are based on the determination of physical and chemical material properties, can be used to describe these processes. Here, the Henry constants describe the concentration equilibrium at the phase interfaces and the diffusion coefficients describe the movement of the gas molecules dissolved in mineral oil. This paper presents mathematically or experimentally determined values and compares them with the literature. Furthermore, it describes the influence of the key gases investigated and the temperature dependence.
\end{abstract}

C. Riedmann, OVE $(\varangle) \cdot$ U. Schichler, OVE

Institut für Hochspannungstechnik und

Systemmanagement, Technische Universität Graz,

Inffeldgasse 18, $8010 \mathrm{Graz}$, Austria

christof.riedmann@tugraz.at

W. Häusler · W. Neuhold

Industrie Automation Graz, Ing. W. Häusler GmbH, Raaba, Austria
Keywords Transformer · Online DGA · Condition monitoring $\cdot$ Henry constants $\cdot$ Diffusion coefficients

\section{Kontinuierliche Gas-in-Öl-Analyse bei Transformatoren - Möglichkeiten, Erfahrungen und Grenzen}

Zusammenfassung In einer Zeit, in der die optimale Verwertung von Ressourcen in den Vordergrund rückt, wird auch die Zustandsüberwachung elektrischer Betriebsmittel immer wichtiger. Hierbei übernimmt die Gas-in-Öl-Analyse als weltweit anerkannte Methode zur Zustandsbewertung von Transformatoren eine wesentliche Schlüsselrolle. Mithilfe eines kontinuierlichen Monitorings der Schlüsselgase in einem Transformator können sich anbahnende Defekte frühzeitig erkannt und geeignete Maßnahmen eingeleitet werden. Durch diese ermöglichte Planung von Instandhaltungsmaßnahmen werden Kosten eingespart und die Gesamtsystemzuverlässigkeit erhöht. Bei frei-atmenden Transformatoren kann es mit der Zeit zu einer Entgasung bzw. zu einer Gasrücksättigung kommen, welche die Interpretationsgrundlage der Gas-in-Öl-Analyse beeinflussen kann. Grund hierfür ist, dass frei bewegliche Moleküle in einem physikalisch-chemischen System stets eine Gleichverteilung anstreben. Zur Beschreibung dieser Vorgänge können verschiedene Theorien herangezogen werden. Die Bestimmung der physikalischen und chemischen Stoffeigenschaften stellt das Fundament dieser Theorien dar. Hierbei dienen die Henry-Konstanten zur Beschreibung des Konzentrationsgleichgewichts an Phasengrenzflächen und die Diffusionskoeffizienten zur Beschreibung der Bewegung der im Mineralöl gelösten Gasmoleküle. In diesem Beitrag werden rechnerisch bzw. empirisch ermittelte Werte präsentiert und mit der Literatur verglichen. Darüber hinaus wer- 
den der Einfluss der untersuchten Schlüsselgase und die Abhängigkeit von der Temperatur beschrieben.

Schlüsselwörter Transformatoren · Kontinuierliche Gas-in-Öl-Analyse · Zustandsüberwachung · HenryKonstanten · Diffusionskoeffizienten

\section{Introduction}

Optimal use of monetary resources is an issue of ever greater importance in the world today, and asset management in the energy sector is also gaining significance. An essential task that goes hand in hand with this, is evaluating the current condition of electrical equipment is. Dissolved gas analysis (DGA) is an accepted procedure worldwide for condition assessment and condition monitoring of transformers. In addition, DGA is the most frequently used procedure to detect incipient faults at an early stage and one that also has the capability to initiate appropriate maintenance measures $[1,2]$.

Naphthenic mineral oil consists primarily of a mixture of hydrocarbon chains $\left(\mathrm{C}_{12} \mathrm{H}_{26}, 11.6 \%\right)$ and alkanes-A cycloalkane $\left(\mathrm{C}_{14} \mathrm{H}_{28}, 15.5 \%\right)$, bicyclic alkanes $\left(\mathrm{C}_{13} \mathrm{H}_{24}, 28.5 \%\right)$, tricyclic alkanes $\left(\mathrm{C}_{16} \mathrm{H}_{28}, 23.3 \%\right)$ and tetracyclic alkanes $\left(\mathrm{C}_{16} \mathrm{H}_{26}, 9.7 \%\right)$ (Fig. 1; [3]). Electrical and/or thermal stresses in the transformer can exceed the binding energy of the carbon-carbon or carbonhydrogen bonds. The bonds break and the resulting instable decomposition products then combine again

$$
\begin{aligned}
& \mathrm{C}_{12} \mathrm{H}_{26} \\
& \mathrm{H}_{3} \mathrm{C}^{-}{ }^{-\mathrm{CH}_{2}} \mathrm{CH}_{2}^{-\mathrm{CH}_{2}} \mathrm{CH}_{2}^{-} \mathrm{CH}_{2} \mathrm{CH}_{2}^{-\mathrm{CH}_{2}}{ }^{-} \mathrm{CH}_{2}^{-} \mathrm{CH}_{2} \mathrm{CH}_{2}^{-\mathrm{CH}_{3}} \\
& \mathrm{C}_{16} \mathrm{H}_{28}
\end{aligned}
$$

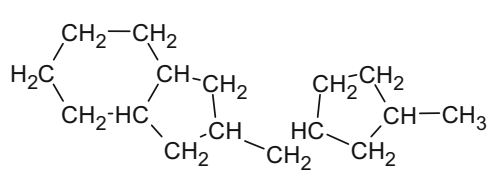

$$
\begin{aligned}
& \mathrm{C}_{14} \mathrm{H}_{28} \\
& \mathrm{C}_{13} \mathrm{H}_{24}
\end{aligned}
$$

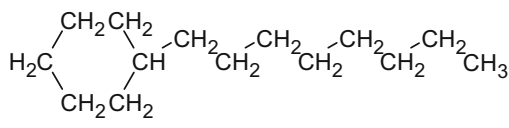

$$
\begin{aligned}
& \stackrel{\mathrm{H}_{2} \mathrm{C}_{2}^{-}}{\mathrm{H}_{2} \mathrm{C}} \underset{\mathrm{CH}_{2}^{-}}{\mathrm{CH}_{2}} \stackrel{\mathrm{CH}_{2}}{\mathrm{CH}_{2}^{-}} \stackrel{\mathrm{HC}}{\mathrm{CH}_{2}} \underset{\mathrm{CH}_{2}}{\mathrm{C}} \mathrm{CH}_{2}^{-\mathrm{CH}_{2}}-\mathrm{CH}_{3} \\
& \mathrm{C}_{16} \mathrm{H}_{26}
\end{aligned}
$$

to form gaseous molecules, which can be present in dissolved and/or free form. The resulting key gases are $\mathrm{H}_{2}, \mathrm{CH}_{4}, \mathrm{C}_{2} \mathrm{H}_{2}, \mathrm{C}_{2} \mathrm{H}_{4}$ and $\mathrm{C}_{2} \mathrm{H}_{6}$. In addition, $\mathrm{CO}$ and $\mathrm{CO}_{2}$, which are produced in combination with atmospheric oxygen and cellulose degradation, as well as $\mathrm{O}_{2}$ are also among the key gases $[4,5]$.

With DGA, the presence or concertation of the key gases is detected within the mineral. There is the possibility of manual sampling including subsequent analysis in the laboratory and the possibility of continuous monitoring systems (online DGA, Fig. 2). In general, the measurement starts with sampling and extraction of the gases dissolved in the oil. A distinction is made between the different extraction methods, with vacuum extraction being the most accurate and the headspace method the most commonly used. In the headspace method, a gas phase consisting of carrier gas is located above the mineral oil to be analysed, into which the dissolved gases diffuse. After the extraction of the gases, their composition is analysed. In most cases, this is done using gas chromatography. Here, the gas mixture (carrier gas + key gases) is forced through a system of tubes and detected on a thermal detector. The gas molecules migrate through the columns of the GC tube at different speeds and then hit the detector at a defined point in time, depending on the physical and chemical properties. Other methods with their own specific advantages and disadvantages are also in use, such as infrared spectroscopy. In this method, the reflection of an infrared light source

Fig. 1 Molecular structures of main components of naphthenic mineral oil, following [3]

Fig. 2 Transformer with online DGA system

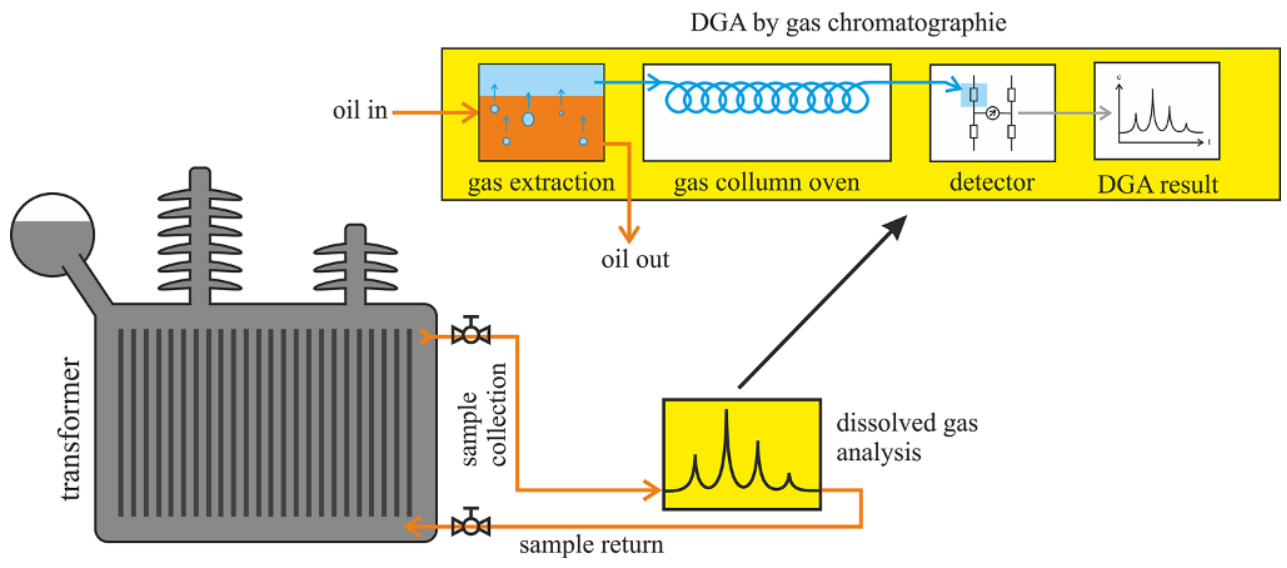


is analysed depending on the gases present. Different gas molecules absorb different frequencies of the IR spectrum to different degrees. The great advantage of this method is very high long-term stability and the maintenance-free nature of the device itself, but not all key gases can be directly detected with this method $[6,7]$.

\section{Condition assessment of transformers by DGA}

It is possible to determine the present condition of the transformer by analysing the gases dissolved in the oil. There are various approaches for data interpretation [8]. One frequently used method is to compare identically designed transformers and define a threshold value at $90 \%$ of the maximum gas concentrations. It is assumed, that the probability of a fault occurring in a transformer at gas concentrations below this threshold is low. If one of these gas thresholds is exceeded, the transformer should be inspected more precisely. If the fleet of transformers is too small or no comparative data is available, reference values from the literature and standards can be used. Trends of recent years have shown that a condition assessment based on absolute gas concentrations can often be insufficient, the rates of gas change are thus increasingly used as an assessment criterion. Here, also, the $90 \%$ value of the gas change rate is defined or reference values can be used $[4,9,10]$. The procedure defined in IEEE C57.104 goes one step further and makes recommendations for action directly on the individual gas concentrations and gas change rates (Table 1; [11]).

Depending on the real instantaneous energy input, typical key gas compositions are formed for different faults (Fig. 3a). A distinction is made between catalytic reactions $\mathrm{R}$, partial discharges of the corona type PD, stray gassing $\mathrm{S}$, thermal faults $\mathrm{T} 1\left(<300^{\circ} \mathrm{C}\right)$,

Table 1 Recommendations for action related to percentage of total combustible gases (TCG) [11]

\begin{tabular}{|c|c|c|c|c|}
\hline & $\begin{array}{l}\text { TCG } \\
(\%)\end{array}$ & $\begin{array}{l}\text { TCG rate } \\
\text { (\%/day) }\end{array}$ & $\begin{array}{l}\text { Sampling } \\
\text { Interval }\end{array}$ & Operating Procedures \\
\hline \multirow[t]{3}{*}{ Condition 4} & \multirow[t]{3}{*}{$\geq 5$} & $>0.3$ & Daily & \multirow{2}{*}{$\begin{array}{l}\text { Consider removal from service; } \\
\text { Advise manufacturer }\end{array}$} \\
\hline & & $0.01-0.3$ & Daily & \\
\hline & & $<0.01$ & Weekly & $\begin{array}{l}\text { Exercise extreme caution; } \\
\text { Analyse for individual gases; } \\
\text { Plan outage; } \\
\text { Advise Manufacturer }\end{array}$ \\
\hline \multirow[t]{3}{*}{ Condition 3} & \multirow[t]{3}{*}{$2-5$} & $>0.3$ & Weekly & \multirow{3}{*}{$\begin{array}{l}\text { Exercise extreme caution; } \\
\text { Analyse for individual gases; } \\
\text { Plan outage; } \\
\text { Advise manufacturer }\end{array}$} \\
\hline & & $0.01-0.3$ & Weekly & \\
\hline & & $<0.01$ & Monthly & \\
\hline \multirow[t]{3}{*}{ Condition 2} & \multirow[t]{3}{*}{$0.5-2$} & $>0.3$ & Monthly & \multirow{3}{*}{$\begin{array}{l}\text { Exercise caution; } \\
\text { Analyse for individual gases; } \\
\text { Determine load dependence }\end{array}$} \\
\hline & & $0.01-0.3$ & Monthly & \\
\hline & & $<0.01$ & Quarterly & \\
\hline \multirow[t]{3}{*}{ Condition 1} & \multirow[t]{3}{*}{$<0.5$} & $>0.3$ & Monthly & $\begin{array}{l}\text { Exercise caution; } \\
\text { Analyse for individual gases; } \\
\text { Determine load dependence }\end{array}$ \\
\hline & & $0.01-0.3$ & Quarterly & \multirow[t]{2}{*}{ Continue normal operation } \\
\hline & & $<0.01$ & Annual & \\
\hline
\end{tabular}

T2 $\left(300^{\circ} \mathrm{C}-700^{\circ} \mathrm{C}\right)$ and $\mathrm{T} 3\left(>700^{\circ} \mathrm{C}\right)$, overheated paper or cellulose $\mathrm{O}$, carbonisation of cellulose $\mathrm{C}$, low energy discharge D1 and high energy discharges D2 [11, 12]. Various mathematical and graphical methods are available for fault identification, which are described in detail in $[6,10]$. The most frequently used methods are the key gas method, the gas concentration ratio method according to Rogers/Doernenburg/IEC and the Duval triangle method (Fig. 3b; [2, 6, 13]).

\section{Benefits of an online DGA monitoring system}

In recent years proof has been provided that knowing the history of a transformer and detecting incipient faults from an early stage is a great advantage. Through continuous monitoring, the condition of a transformer can be determined more accurately and maintenance measures can be more effectively planned (Fig. 4). This leads to better allocation of available monetary and material resources and an increase in overall system reliability $[1,14]$. An essential part of this is to know exactly the rates of change of dissolved gases in a transformer-they are considered a more important indicator than the absolute gas concentrations [9]. The assessment of the transformer condition based on absolute gas concentrations can lead to incorrect estimates. The same amount of dissolved gas can be assessed with a different criticality in different transformers $[4,13,14]$. Furthermore, gas concentrations in different transformers can be attributed to different causes. There are transformers with highly increased gas concentrations that have been operating stably for many years and show no or only very small further increases. This might indicate an inactive fault, which can lead to a failure within a short time if it begins to evolve again. It is advisable to aim for continuous monitoring of the transformer. Other transformers show very rapid increases in dissolved gases in a very short time, which cannot be detected in time by regular sampling [9].

The fact that the condition of a transformer can change rapidly is shown by the case of a $23.5 / 432 \mathrm{kV}$ generator step-up transformer, where a multi-gas DGA monitoring system was installed in 2010. Up to that time, the transformer did not show any significant gas concentrations. Shortly after installation, there was a sharp increase in $\mathrm{H}_{2}$ and $\mathrm{C}_{2} \mathrm{H}_{2}$, indicating an electrical fault (Fig. 5). For safety reasons, the transformer was taken off the grid, subjected to electrical tests and maintenance work. The electrical tests did not lead to a result, but forensic examinations showed a developing electrical fault in the winding with an already advanced decomposition of the paper insulation (degree of polymerisation, $\mathrm{DP}<200$ ) [13]. The DP value corresponds to the number of interconnected glucose rings of the cellulose. It provides information about the current condition of the paper insulation and has a direct correlation to the remaining service life. The number of interconnected 

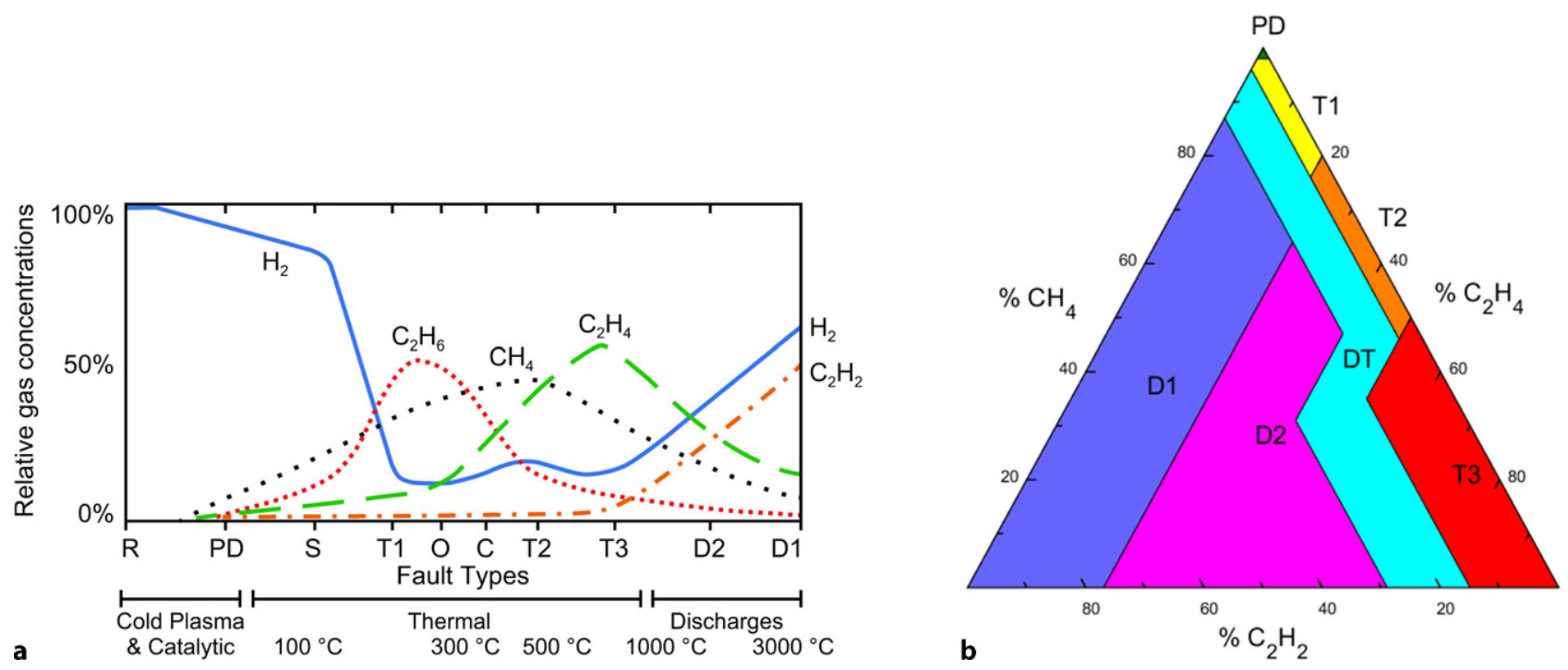

Fig. 3 Distribution of key gases for different faults in percentage (a) and Duval triangle one (b)

Fig. 4 380/110-kV transformer with a DGA monitoring system (a) and the DGA monitor itself (b)
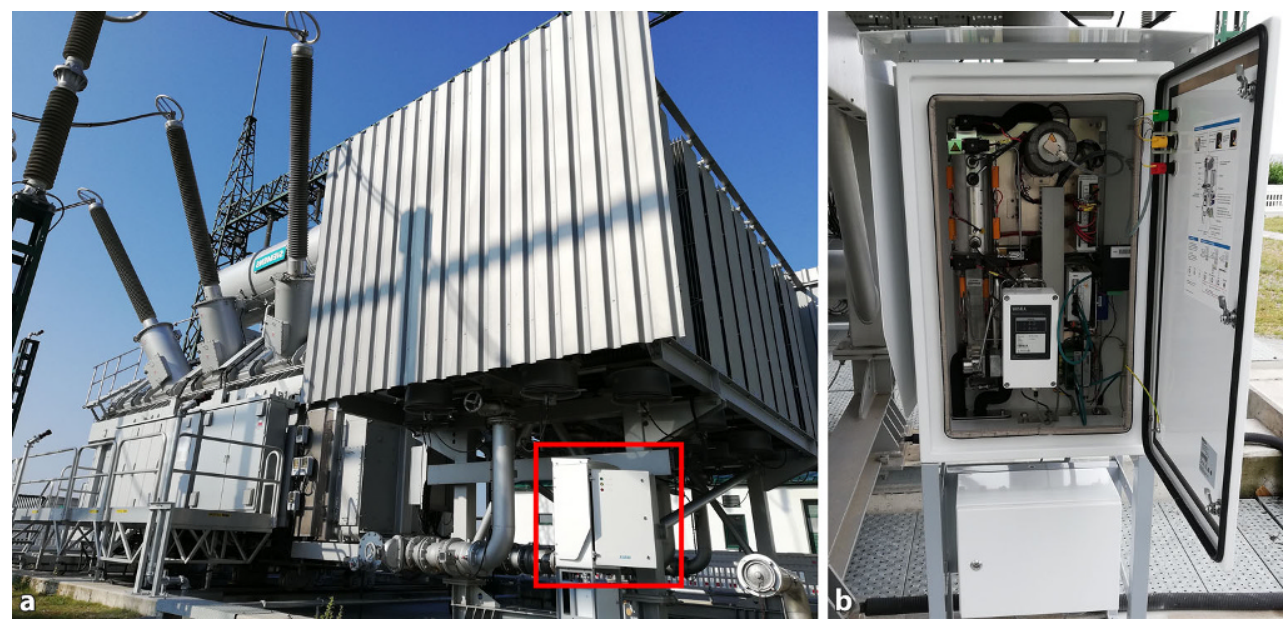

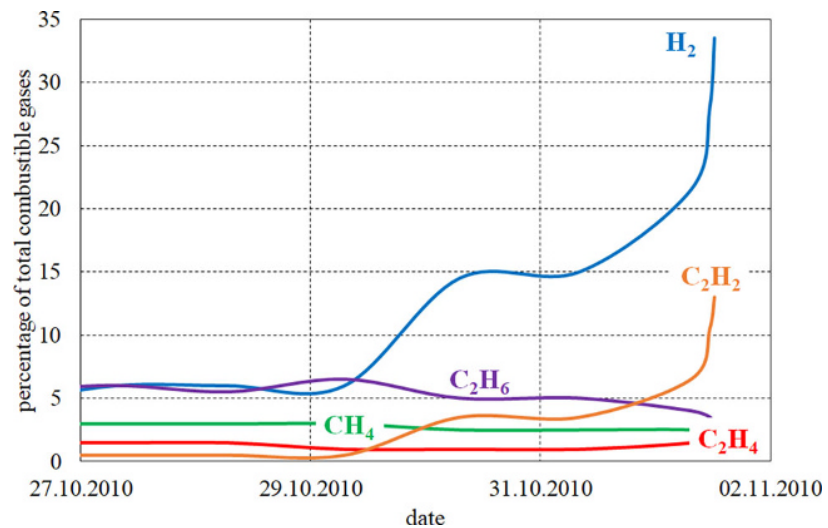

Fig. 5 Time dependent dissolved gas concentrations in a 23.5/432 kV GSU transformer, based on [13]

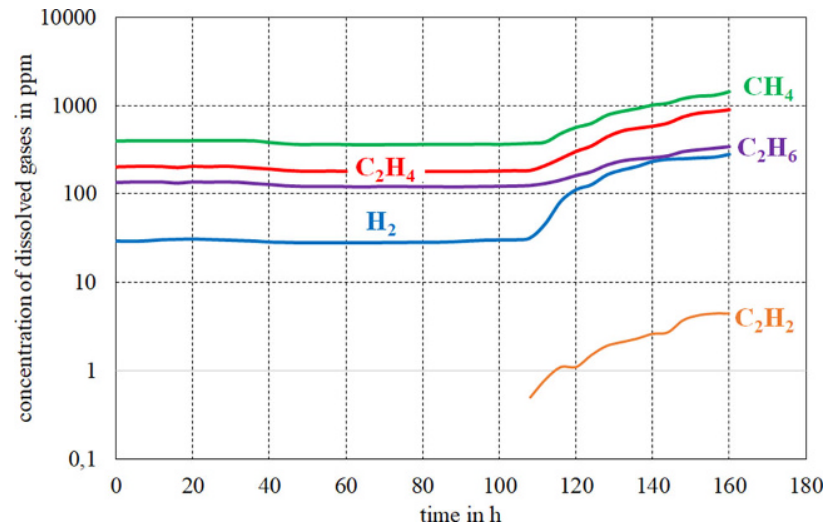

Fig. 6 Time dependent dissolved gas concentrations in a $345 \mathrm{kV}$ GSU transformer, based on [12] 
glucose rings in new transformers is in the range of 1000 to 1200 . When this value is less than 200 , it can be assumed that the paper quality is no longer sufficient for reliable operation [8].

In [14], five cases are described in which a DGA monitoring system was able to successfully identify incipient faults at an early state. Of particular interest is the case of a $735 / 230 \mathrm{kV}$ transformer where a fault in the bushing area was detected in time by an increase in $\mathrm{H}_{2}$. Consequently, the transformer load was reduced and the transformer could be taken off the grid and maintained within 40 days as planned. The estimated cost saving due to the early detection of the fault and the corresponding repair of the transformer is estimated to be around $\$ 4,000,000$.

A somewhat more recent example from [12] also shows that gas concentrations can increase rapidly within a short time (Fig. 6). The evaluation of the data with all methods showed that there is a thermal fault and the scenario described in [11] requests immediate action. The integrated Buchholz relay did not trigger in this case and the transformer was manually taken off the grid. The inspection carried out showed severe carbonisation of the paper insulation.

In general, any incipient fault is accompanied by the formation of hydrogen (compare Fig. 3a). In many cases, a hydrogen sensor is sufficient for monitoring and enables a simple realisation of a monitoring system. The interpretation basis for a developing defect and also its classification is strongly limited, however, since historical data is only available for $\mathrm{H}_{2}$ or a few other gases. Hydrogen is not always available in sufficient quantities for thermal defects such as those that occur with broken or loose connections, overheating cores, poor cooling, eddy currents, etc. The so-called "hot metal gases" $\left(\mathrm{CH}_{4}, \mathrm{C}_{2} \mathrm{H}_{6}\right.$ and $\left.\mathrm{C}_{2} \mathrm{H}_{4}\right)$ are of central importance here. Furthermore, the increase of $\mathrm{C}_{2} \mathrm{H}_{2}$ as a significant sign for electrical discharges is not present. $\mathrm{C}_{2} \mathrm{H}_{2}$ can indicate a significant fault from concentrations of a few ppm. In the case of stray gassing, there is also a large increase in $\mathrm{H}_{2}$, although this is not a defect with consequences [12]. It can thus be stated that monitoring with an $\mathrm{H}_{2}$ sensor is better than no monitoring at all, but each additional key gas increases the overall system reliability and prevents costly failures. The recognised disadvantage of multigas monitoring systems is the purchase price, but this is negligible compared to the cost of a power transformer failure.

\section{Gas balance of transformers for DGA interpretation}

\subsection{Degassing at the phase interface}

In the case of free-breathing transformers, which are primarily used in Europe, gas exchange occurs at the phase interface between the mineral oil and the gas phase above $[15,16]$. This exchange can be

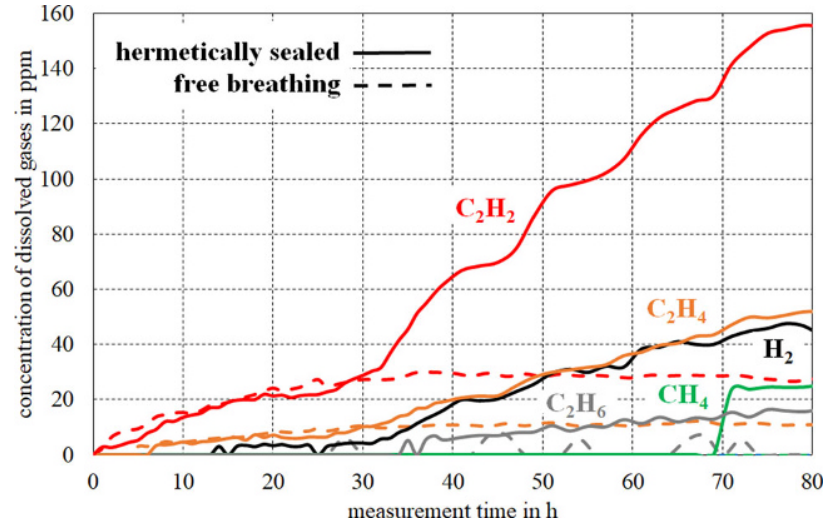

Fig. 7 Time dependent gas generation in a hermetically sealed and a free breathing arangement [17]

explained by the desired equal distribution of free moving molecules in a closed chemical-physical system. After the appearance of an electrical or thermal fault, very high gas concentrations are formed locally at the point of the fault due to the decomposition of the mineral oil and possibly of the cellulose. Subsequently, the dissolved and free gas molecules are distributed throughout the entire system. This balancing process is composed of free diffusion and superimposed convection flows. Consequently, an equilibrium is established between the gas phase and the mineral oil, which means that key gases are degassed into the gas phase and gases from the gas phase dissolve in the mineral oil $[2,15,17]$.

Although this method is not generally recommended today, the condition of a transformer, as well as its warning and alarm gas values, are determined using the absolute gas concentrations $[9,11]$. Due to the continuous degassing with simultaneous gas formation, a state of equilibrium is established between these two processes. This equilibrium does not necessarily reflect the actual state of the transformer $[15,18,19]$. Fig. 7 shows the concentrations of dissolved gases in the case of a continuous surface discharge over time in a laboratory experiment. It can be seen that in the free-breathing configuration, an equilibrium between degassing and gas formation already occurs, whereas this does not occur in the hermetically sealed configuration. Furthermore, the degassing of $\mathrm{H}_{2}$ and $\mathrm{CH}_{4}$ takes place so quickly that no measurable concentrations arise in the test object. This may also lead to a different interpretation of the defect [17].

\subsection{Dissolving air gases and their temperature behaviour}

The opposite case to the degassing of transformers is the dissolving of ambient air gases from the atmospheric ambient air during initial commissioning or after degassing of the mineral oil [16]. Own measurements showed a saturation concentration of about 

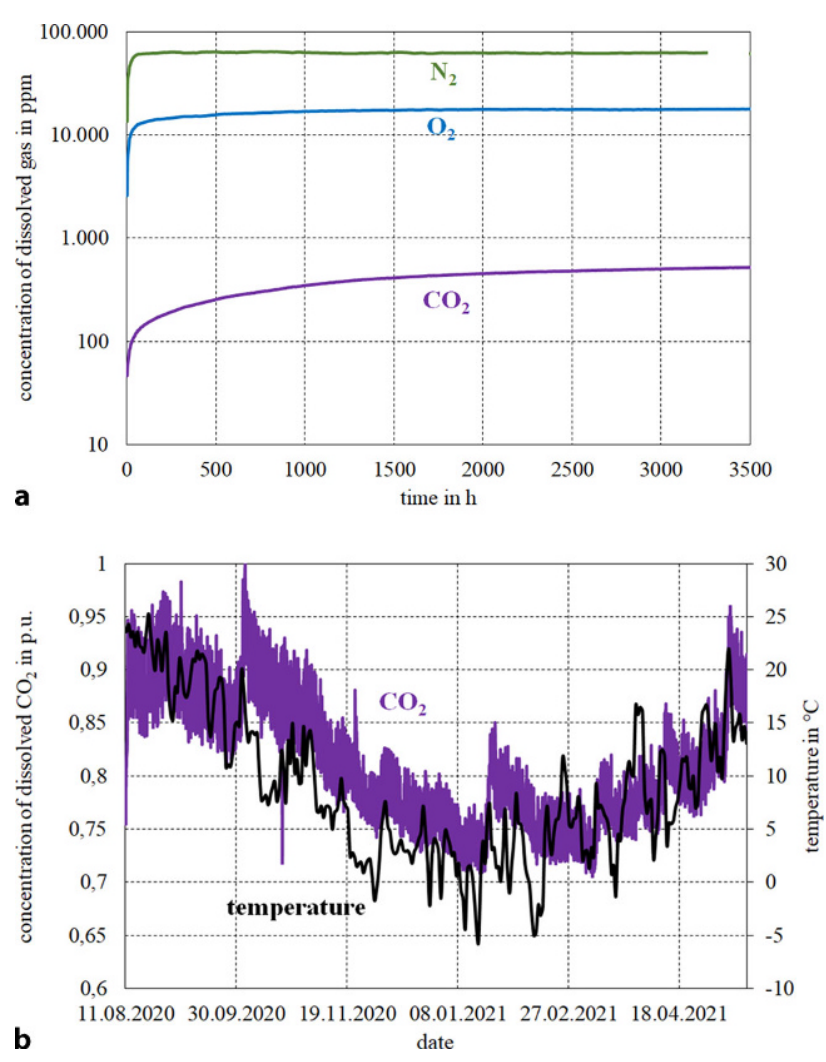

Fig. 8 Dissolving of $\mathrm{N}_{2}, \mathrm{O}_{2}$ and $\mathrm{CO}_{2}$ from ambient air in mineral oil of a 200 I transformer model in the laboratory (a) and temperature and concentration of dissolved $\mathrm{CO}_{2}$ over time of a in service $110 / 380 \mathrm{kV}$ transformer (b)

$63,000 \mathrm{ppm}$ for $\mathrm{N}_{2}, 18,000 \mathrm{ppm}$ for $\mathrm{O}_{2}$ and $500 \mathrm{ppm}$ for $\mathrm{CO}_{2}$ (Fig. 8a). It can also be seen that different gases dissolve in the mineral oil with different velocities.

In addition, different concentrations of dissolved gases can occur depending on temperature fluctuations due to changes in the load or the ambient temperature. On the one hand, this is due to the temperature dependence of Henry's constant, which describes the gas solubility in mineral oil, and the gas storage capacity of cellulose. Fig. 8b shows this behaviour based on measurements at a $110 / 380 \mathrm{kV}$ transformer.
The concentration of $\mathrm{CO}_{2}$ is stated in p. u. with reference to the maximum value of the concentration in the period under consideration.

\section{Current research on chemical and physical properties for DGA interpretation}

\subsection{General}

As mentioned above, gas exchange occurs in the area of the phase interface. Dissolved gas molecules in the mineral oil diffuse into the gas phase and gas molecules from the air or the gas cushion dissolves in the mineral oil. Since different substances have varying solubilities, different gases degas at unequal rates. This leads to a shift in the relative proportions of the gases and makes it difficult to identify the fault by established methods like the ratio methods or Duval triangles [17].

For decades, the DGA has been a well-suited and approved method for assessing and monitoring the condition of transformers. By taking the gas exchange into account, the DGA could be further improved. An even more precise assessment of the current condition would be possible and the accuracy of interpretation would be increased. For this purpose, a mathematical model based on the various mass transport theories is being developed and tested at the Institute of High Voltage Engineering and System Performance. In future, this model should be able to quantify the degassing at the phase interface between the mineral oil and the overlying gas blanket or the ambient air [18].

In general, all transfer and transport processes are subject to comparable physical laws and are described by similar effects. The mass transfer is understood to be a change in quantity in a time interval. The diffusion coefficients and the Henry constants are considered to be the determining parameters for the characteristics of mass transfer. The diffusion coefficients determine the relationship between concentration gradient and diffusive mass transfer. The Henry constants describe the concentration equilib-
Fig. 9 Setup for measuring Henry constants

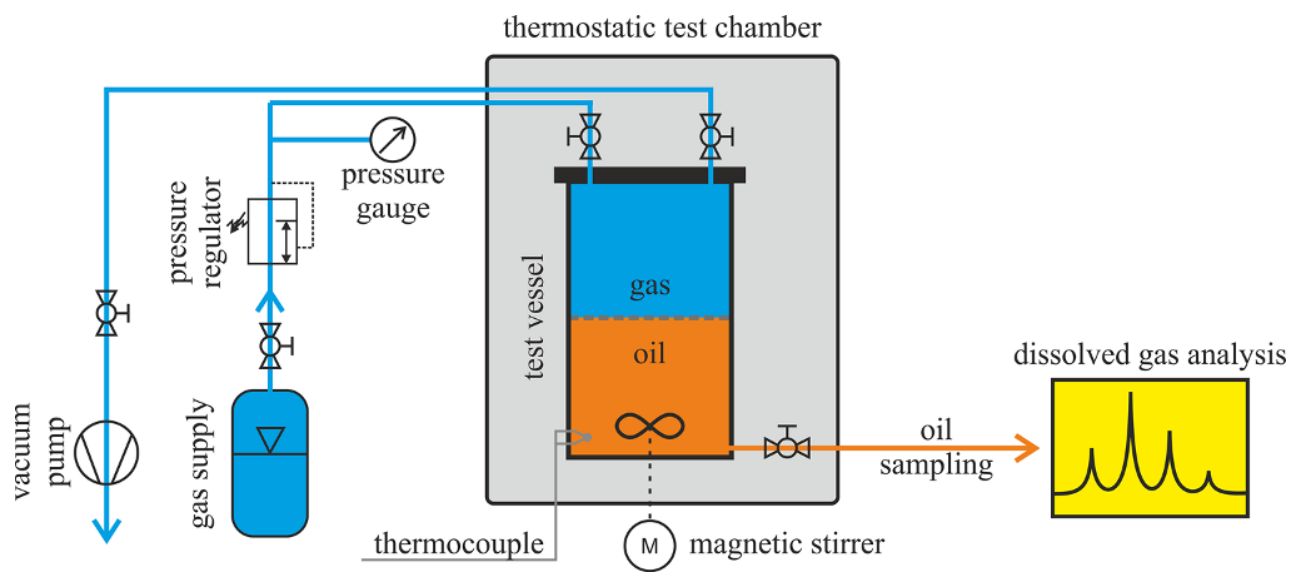


rium between the liquid and gaseous phase at the phase interface $[18,20]$.

The Henry constants of gas i are based on own investigations and are determined experimentally as described in [21]. The schematic test setup is shown in Fig. 9. The oil samples taken after saturation are analysed in the laboratory for the corresponding concentration $c_{\mathrm{i}}$. Then, $c_{\mathrm{i}}$ is set in relation to the measured gas pressure $p_{\mathrm{i}}$ and the Henry constant $H_{\mathrm{i}}$ results (Eq. 1).

$$
H_{i}=\frac{p_{i}}{c_{i}} \text { in } \mathrm{Pa} / \mathrm{ppm}
$$

The diffusion coefficient $D$ describes the relationship between a concentration gradient and the diffusion flux. An exact determination is only possible empirically-e.g. measurement with a diaphragm diffusion cell. In practice, mathematical approximations are often used, but these can be of very variable quality. The values of the diffusion coefficients increase with rising temperature and pressure [20, 22]. The most commonly used approaches are the Stokes-Einstein equation (Eq. 2, $k$ Boltzmann constant, $T$ temperature, $\eta$ dynamic viscosity of the solvent, $R_{0}$ Vander-Waals radius) and the approach of Wilke and Chang (Eq. 3, $\varphi$ association factor of the solvent, $M_{\mathrm{m}, 2}$ molecular mass of the solvent, $V_{\mathrm{m}, 1}$ molar volume of the diffusing species at the boiling point under normal conditions, $\eta_{2}$ to the viscosity of the liquid, $T$ temperature) [20, 23-25].

$$
\begin{aligned}
& D=\frac{k T}{6 \pi \cdot \eta \cdot R_{0}} \\
& D=7,4 \cdot 10^{-8}\left(\left(\varphi \cdot M_{m, 2}\right)^{1 / 2} \cdot \frac{T}{\eta_{2} \cdot V_{m, 2, S}^{0,6}}\right)
\end{aligned}
$$

Another empirical approach is provided by the American Petroleum Institute (API), which is specifically designed to determine diffusion coefficients of dissolved gases in petroleum liquids (Eq. 4, $D_{1,2}$ in $\mathrm{ft}^{2} / \mathrm{h}, T$ in ${ }^{\circ} \mathrm{Ra}, \eta_{2} \mathrm{cP}, R$ in $\AA$ ) [26].

$$
D=5,922 \cdot 10^{-8} \cdot \frac{T \cdot R_{2}}{\eta_{2} \cdot R_{1}^{2 / 3}}
$$

\subsection{Results and interpretation}

\subsubsection{Henry constants}

The experiments carried out clearly show that various gases behave differently with increasing temperature. The solubility of the investigated hydrocarbons $\left(\mathrm{C}_{2} \mathrm{H}_{2}\right.$, $\mathrm{C}_{2} \mathrm{H}_{4}, \mathrm{C}_{2} \mathrm{H}_{6}$ and $\mathrm{CH}_{4}$ ) increases with rising temperature, whereas the solubility of hydrogen $\left(\mathrm{H}_{2}\right)$ decreases with increasing temperature (Fig. 10). This behaviour is also consistent with the available results [19, 27-30]. It should be noted that the Ostwald coefficients have an opposite behaviour since the Ostwald coefficients roughly correspond to the reciprocal of the respective Henry's constants [21].

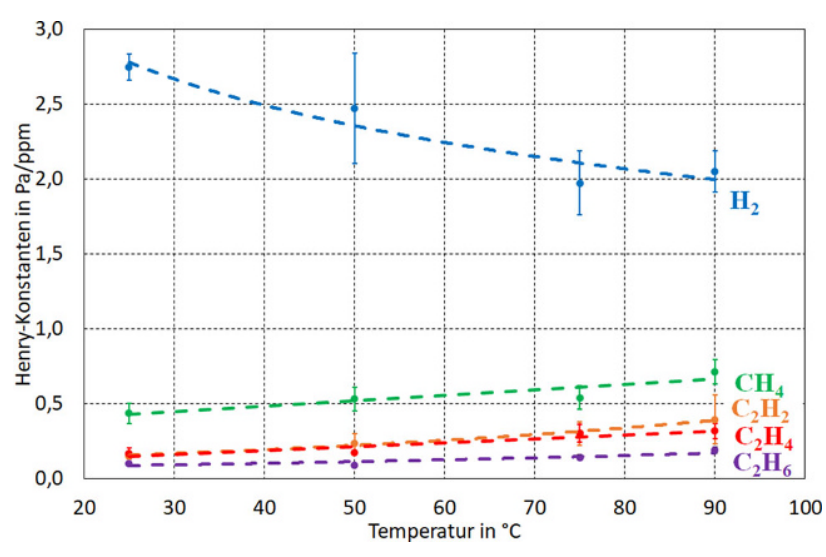

Fig. 10 Henry constant of different gases over temperature

An actual comparison of the measured and calculated Ostwald coefficients with values from the literature is only possible to a limited extent, as there is no indication of the exact definition of the Ostwald coefficients used $[4,11]$. However, the chosen definition variant has a strong influence on the expected value [29]. Furthermore, the values in $[4,11]$ reflect averaged values and the density of the oil used has a significant influence on the actual values of the coefficients and constants [30]. A more detailed look at the values in Table 2 shows that the differences to the values in the literature are relatively large but the values are in the same order of magnitude. The conversion between the Henry constants and Ostwald coefficients was carried out according to [30].

\subsubsection{Diffusion coefficients}

A deeper look at the calculation results of the diffusion coefficients for different key gases $\left(\mathrm{C}_{2} \mathrm{H}_{2}, \mathrm{C}_{2} \mathrm{H}_{4}, \mathrm{C}_{2} \mathrm{H}_{6}\right.$, $\mathrm{H}_{2}$ and $\mathrm{CH}_{4}$ ) shows that they not only increase with rising temperature but that there are also significant differences between the individual gases and calculation procedures (Fig. 11).

The non-linear increase with temperature results from the fact that not only is the temperature directly linear (cf. Eqs. 2 to 4 ) but other parameters such as viscosity, radii and volumes are also temperature-dependent.

In the Wilke and Chang method, the value of the boiling point has the greatest influence on the slope of

\begin{tabular}{|c|c|c|c|c|}
\hline & Henry Constants & Ostwald Coeffici & & \\
\hline & Measurements & Calculations & [4] & [11] \\
\hline & $\mathrm{Pa} / \mathrm{ppm}$ & & & \\
\hline $\mathrm{H}_{2}$ & $2.746( \pm 0.089)$ & $0.079( \pm 0.003)$ & 0.056 & 0.043 \\
\hline $\mathrm{CH}_{4}$ & $0.437( \pm 0.065)$ & $2.563( \pm 0.351)$ & 0.429 & 0.337 \\
\hline $\mathrm{C}_{2} \mathrm{H}_{2}$ & $0.155( \pm 0.021)$ & $7.244( \pm 0.898)$ & 1.240 & 0.937 \\
\hline $\mathrm{C}_{2} \mathrm{H}_{4}$ & $0.135( \pm 0.036)$ & $7.781( \pm 2.092)$ & 1.840 & 1.350 \\
\hline $\mathrm{C}_{2} \mathrm{H}_{6}$ & $0.112( \pm 0.009)$ & $9.944( \pm 0.817)$ & 2.820 & 1.990 \\
\hline
\end{tabular}
the curve, as this has a decisive influence on the molar

Table 2 Comparison of own measurements with values from literature at $25^{\circ} \mathrm{C}$ 


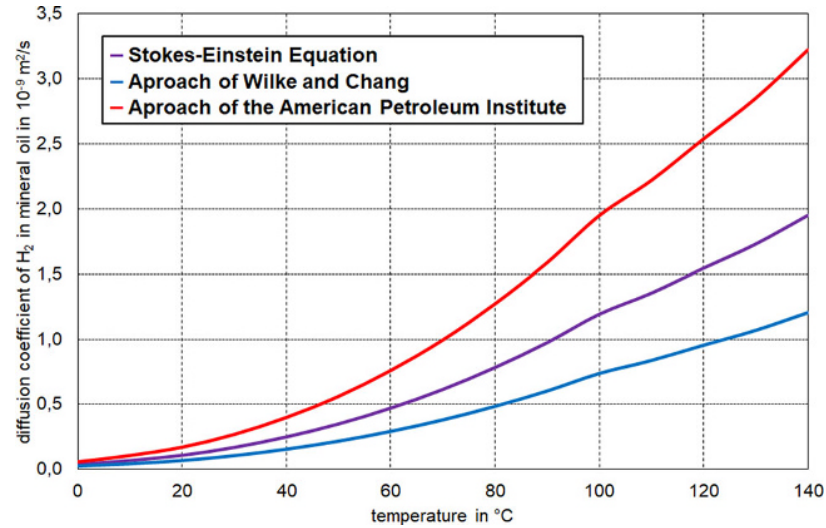

Fig. 11 Temperature dependent diffusion coefficients of hydrogen, determined with the help of different calculation methods

volume. In the literature, the results determined for the diffusion coefficients vary in the range of $10^{-8} \mathrm{~m}^{2} / \mathrm{s}$ and $10^{-11} \mathrm{~m}^{2} / \mathrm{s}$. The values determined using the approximation formula are within this range (Table 3). For the first calculations, the determined values can be used, but for a more precise later consideration, measurements of the diffusion coefficients should be carried out [31-33].

\section{Summary}

The optimal utilisation of resources and thus also the condition assessment of electrical equipment in the power engineering sector is becoming increasingly important. DGA has been used to evaluate and monitor the current condition of transformers for many decades. In addition to the absolute gas concentrations, the rate of gas increase has become more and more important for the assessment in recent years. Trend analysis allows a more precise determination of the actual state due to the trend evaluation. Different standards offer guidelines for threshold values on the one hand and clear recommendations for measures based on the gas trends on the other. With the help of online DGA monitoring systems, incipient faults can be detected at an early stage and appropriate maintenance measures can be initiated. Through

Table 3 Calculated values for the diffusion coefficients of different gases in mineral oil at $20^{\circ} \mathrm{C}$ and comparative values from the literature

\begin{tabular}{|c|c|c|c|c|c|}
\hline & \multicolumn{2}{|l|}{ Calculations } & \multicolumn{3}{|c|}{ Reference } \\
\hline & $\begin{array}{l}\text { Stokes and } \\
\text { Einstein }\end{array}$ & $\begin{array}{l}\text { Wilke and } \\
\text { Chang }\end{array}$ & API-TD-Book & [32] & [33] \\
\hline & $\mathrm{m}^{2} / \mathrm{s}$ & & & & \\
\hline $\mathrm{H}_{2}$ & $1.06 \cdot 10^{-10}$ & $1.36 \cdot 10^{-11}$ & $1.70 \cdot 10^{-10}$ & $1.81 \cdot 10^{-10}$ & $2.10 \cdot 10^{-8}$ \\
\hline $\mathrm{CH}_{4}$ & $6.72 \cdot 10^{-11}$ & $6.86 \cdot 10^{-11}$ & $1.26 \cdot 10^{-10}$ & $4.65 \cdot 10^{-11}$ & $6.01 \cdot 10^{-9}$ \\
\hline $\mathrm{C}_{2} \mathrm{H}_{2}$ & $6.09 \cdot 10^{-11}$ & $4.97 \cdot 10^{-11}$ & $1.18 \cdot 10^{-10}$ & $3.72 \cdot 10^{-11}$ & $4.46 \cdot 10^{-9}$ \\
\hline $\mathrm{C}_{2} \mathrm{H}_{4}$ & $6.05 \cdot 10^{-11}$ & $5.16 \cdot 10^{-11}$ & $1.17 \cdot 10^{-10}$ & $2.77 \cdot 10^{-11}$ & $3.92 \cdot 10^{-9}$ \\
\hline $\mathrm{C}_{2} \mathrm{H}_{6}$ & $5.75 \cdot 10^{-11}$ & $5.35 \cdot 10^{-11}$ & $1.13 \cdot 10^{-10}$ & $2.31 \cdot 10^{-11}$ & $3.63 \cdot 10^{-9}$ \\
\hline
\end{tabular}

planned and timely maintenance measures, financial resources can be saved and the overall system reliability can be increased.

Current research is focused on the phase interface between the mineral oil and the gas phase in the conservator tank, where an exchange of gas molecules occurs. This exchange means that key gases dissolved in the oil dissipate into the ambient air and, vice versa, gases from the ambient air are dissolved in the mineral oil. The basis of interpretation of the DGA is consequently affected. This can lead to a wrong assessment of a fault criticality and to a fault being classified incorrectly. The exchange of gas molecules can be described using various theories of mass transfer. All these theories have in common that the basis is formed by the diffusion coefficients as well as the Henry constants. Currently, a model based on these theories is being developed.

The Henry constants can only be determined exactly by empirical means and they are strongly dependent on the temperature. A comparison of the determined values and the values from the literature shows that large differences sometimes occur between all values. This is primarily due to how the results are determined and the strong dependence on the density of the oil used. It can be seen that the Henry constants of hydrocarbons increase with temperature, whereas those of pure substances decrease. Furthermore, the absolute values of different gases differ greatly. The diffusion coefficients were calculated in this work and it can be seen that significant differences are dependent on both the equation used and the temperature. The literature also shows a very large range of error over several powers of ten. It would therefore appear appropriate in the view of the authors that an experimental procedure for the determination of the diffusion coefficients should be applied in further work.

Acknowledgements The authors would like to thank the "Österreichische Forschungsförderungsgesellschaft FFG" (FFG project number 874800) for financial support in carrying out the presented research activities.

Funding Open access funding provided by Graz University of Technology.

Open Access This article is licensed under a Creative Commons Attribution 4.0 International License, which permits use, sharing, adaptation, distribution and reproduction in any medium or format, as long as you give appropriate credit to the original author(s) and the source, provide a link to the Creative Commons licence, and indicate if changes were made. The images or other third party material in this article are included in the article's Creative Commons licence, unless indicated otherwise in a credit line to the material. If material is not included in the article's Creative Commons licence and your intended use is not permitted by statutory regulation or exceeds the permitted use, you will need to obtain permission directly from the copyright holder. To view a copy of this licence, visit http://creativecommons.org/licenses/by/4.0/. 


\section{References}

1. Mehta D, Kundu P, Chowdhury A, Lakhiani V (2015) DGA diagnostics save transformers-case studies. India, vol 2015. International Conference on Condition Assessment Techniques in Electrical Systems (CATCON), Bangalore

2. Riedmann C, Schichler U, Preusel J, Hämel K (2018) Messung von zeitabhängigen Gaskonzentrationen in Isolierflüssigkeiten mit Hilfe einer kontinuierlichen Gas-in-ÖlAnalyse. VDE, Fachtagung Hochspannungstechnik, Berlin, Germany

3. Liao R-J, Zhu M-Z, Yang L-J, Zhou X, Gong C-Y (2011) Molecular dynamics study of water molecule diffusion in oil-paper insulation materials. Phys B: Condens Matter 406(5):1162-1168. https://doi.org/10.1016/j.physb.2010. 12.074

4. DIN EN 60599:2016: "In Betrieb befindliche, mit Mineralöl befüllte elektrische Geräte - Leitfaden zur Interpretation der Analyse gelöster und freier Gase".

5. Imani M, Farahani M, Kuhnke M, Homeier K, Werle P (2017) "Measuring Methods for Solubility of Gases in Insulation Liquids". 19th International Conference on Dielectric Liquids (ICDL). , Manchester, UK

6. Bakar N, Abu-Siada A, Islam S (2014) A review of dissolved gas analysis measurement and interpretation techniques. Ieee Electr Insulation Mag 30(3):39-49

7. CIGRE JWG D1/A2: “DGA Monitoring Systems”. Technical Brochure 783,2019

8. Werle P, Hartje M (2018) Möglichkeiten und Grenzen von offline Diagnosemethoden zur Zustandsbeurteilung von Leistungstransformatoren. Elektrotechnik Informationstechnik Springer Verl Vol 135(8):514-519. https://doi.org/ 10.1007 / s00502-018-0655-y

9. Ward S (2003) "Evaluating transformer condition using DGA oil analysis". Conference on Electrical Insulation and Dielectric Phenomena. USA, Albuquerque, NM

10. CIGRE JTF D1.01/A2.11: "Recent Developments in DGA Interpretation". Technical Brochure 296, 2006

11. Std IEEE C57 (2019) IEEE :104-2019 (Guide for the Interpretation of Gases Generated in Mineral Oil-Immersed Transformers"). https://doi.org/10.1109/IEEESTD.2019. 8890040

12. CIGRE JWG D1/A2.47: "Advances in DGA Interpretation". Technical Brochure 771,2019

13. Ding $\mathrm{H}$ et al (2017) "Practical experience of dissolved gas in transformer oil for the detection of incipient faults". 19th International Conference on Dielectric Liquids (ICDL). Manchester, UK

14. Gibeault J-P, Kirkup J (1995) "Early detection and continuous monitoring of dissolved key fault gases in transformers and shunt reactors". Electrical Manufacturing et Coil Winding Conference. IL, USA, Rosemont

15. Müller A (2016) Fehlergasverluste frei-atmender Leistungstransformatoren. Dissertation, Universität Stuttgart

16. Bräsel E, Bräsel O, Sasum U (2010) Gashaushalt bei Transformatoren der offenen Bauart - Neue Erkenntnisse. Ew Dossier Transform 109:56-59

17. C. Riedmann, U. Schichler: "Online DGA-State of the Art and Influencing Parameters". International Conference on Condition MonitoringDiagnosis and Maintenance. CMDM 2019 (5th edition), Bucharest, Romania, 2019, pp 250-257

18. Riedmann C, Schichler U (2020) A physical model for the improvement of DGA-based condition assessment of power transformers.8th International Conference on Condition Monitoring and Diagnosis (CMD 2020)_Virtual Conference, Phuket, Thailand, 2020. 978-2-7281-5931$7 / 20 / \$ 31.00$ @2020 IEEE
19. Gómez J (2014) Experimental Investigations on the Dissolved Gas Analysis Method (DGA) through Simulation of Electrical and Thermal Faults in Transformer Oil. Dissertation, Universität Duisburg-Essen

20. Kraume M (2020) Transportvorgänge in der Verfahrenstechnik. Springer Berlin Heidelberg,

21. Mahendrayana I, Riedmann C, Schichler U (2020) Suwarno: "Determination and Comparison of Temperature Dependent Henry Constants for the DGA". 55th International Universities Power. Engineering, Conference (UPEC)—Virtual Conference

22. Jamialahmadi M, Emadi M, Müller-Steinhagen H (2006) Diffusion coefficients of methane in liquid hydrocarbons at high pressure and temperature. J Petroleum Sci Eng 53:47-60. https://doi.org/10.1016/j.petrol.2006.01.011

23. Draxler J, Siebenhofer M (2014) Verfahrenstechnik in Beispielen. Springer,

24. WilkeC, Chang P (1955) Correlation of diffusion coefficients in dilute solutions. AIChE 1:264-270

25. Edward J (1970) Molecularvolumes and the Stokes-Einstein equation. JChemEduc 47(4):261-270

26. EPCON International and the American Petroleum Institute: "APITechnical Data Book-Petroleum Refining". 2005

27. Baker A (1975) Solubility of Gases in Transformer Oil. 42nd International Conference of Doble. Clients

28. T. Oommen: "Adjustments to Gas-in-Oil Analysis Data Due to Gas Distribution Possibilities in Power Transformers". IEEE Transaction on Power Apparatus and Systems, PAS101, No. 6, 1982, pp 1716-1722

29. Battino R (1984) The Ostwald coefficient of gas solubility. Fluid Phase Equilib 15(3):231-240. https://doi.org/10. 1016/0378-3812(84)87009-0

30. ASTM International (2020) Standard test method for estimation of solubility of gases in petroleum liquids. ASTM D2779-92. https://doi.org/10.1520/D2779-92R20

31. Asfour A-F, Dullien F (1983) Diaphragm diffusion cell: Simpler cell design and new equation to calculate diffusivities. AIChE 29(2):347-349. https://doi.org/10.1002/aic. 690290226

32. Wang X, Tang C, Huang B, Hao J, Chen G (2018) Review of research progress on the electrical properties and modification of mineral insulating oils used in power transformers. Energies. https://doi.org/10.3390/en1 1030487

33. Ye W et al (2019) Difference analysis of gas molecules diffusion behavior in natural ester and mineral oil based on molecular dynamic simulation. Mol Vol. https://doi.org/ $10.3390 /$ molecules 24244463

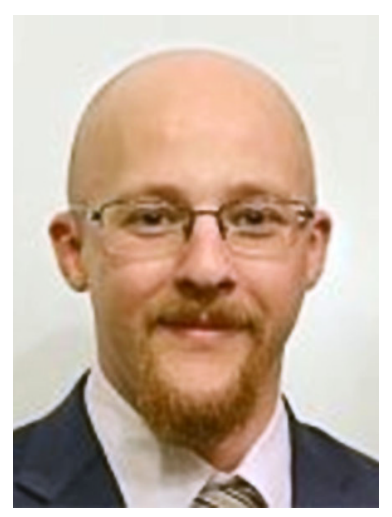

Christof Riedmann, was born in Feldkirch in Vorarlberg in 1990. He completed his master's degree in electrical engineering and economics at Graz University of Technology in April 2017. Since then, he has been working as a scientific research assistant at the Institute of High Voltage Engineering and System Performance, working in the field of condition assessment of electrical equipment such as transformers, capacitors, generators, and overhead lines. He has extensive knowledge in the field of PD diagnostics and dissolved gas analysis. 


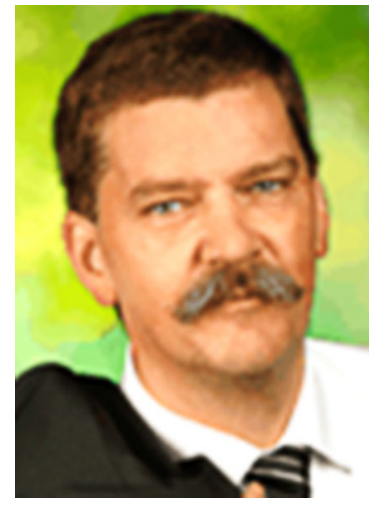

Uwe Schichler, is the head of the Institute of High Voltage Engineering and Systems Performance at Graz University of Technology since 2014. He studied electrical engineering and received his $\mathrm{Ph}$.D. at the Schering Institute of the University of Hanover in 1996. He then worked for Siemens in the field of gas insulated switchgear and transmission lines. $\mathrm{He}$ is a member of OVE, VDE, IEEE, and CIGRE and participates in several CIGRE working groups. He was awarded the "CIGRE Technical Award" of the D1 study committee. Since 2014 he is Austrians representative in the CIGRESCB3 “Switchgear". Current research interests are in the field of condition assessment of electrical equipment, partial discharge measurements, cable technology, andDCinsulation systems.

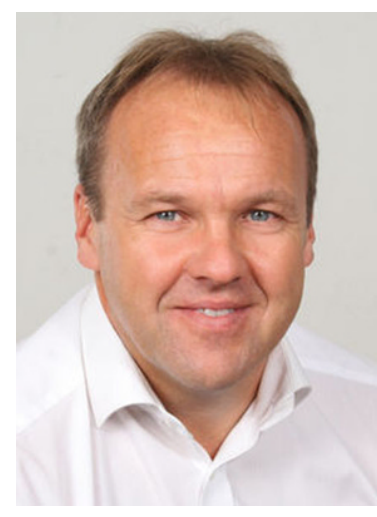

Wolfgang Häusler, was born in 1964 in Graz and graduated from the HTL Graz BULME specializing in communications engineering in 1984. Afterward he worked as a service and project technician in the field of process automation. Since 1990 he has been working independently in the field of measuring physical quantities, with a focus on humidity and temperature, and gas compositions, and has acquired a wealth of knowledge over the years.

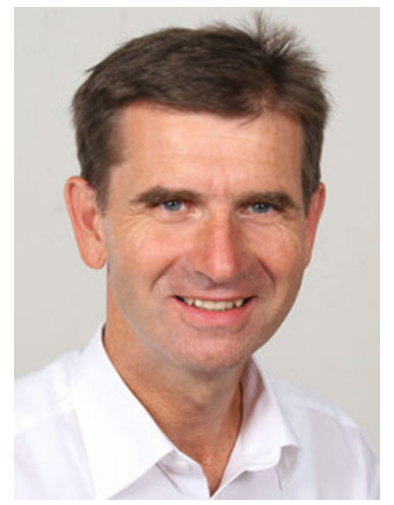

Wolfgang Neuhold, was born in Graz in 1963. He finished school with A levels in 1982 at the BG Pestalozzi in Graz. Since 1997 he has been employed as a technical employee at Ing. W. Häusler $\mathrm{GmbH}$ (IAG). During this time he completedvarioustechnical and commercial training courses. $\mathrm{He}$ is the product manager for moisture meters, gas sensors and analyzers. 